\title{
INDEX OF AUTHORS.
}

Advisory Committee. Reports on Plague Investigations in India [issued by the Advisory Committee]. (Continued from vol. viI, p. 986.) [Fourth Plague Number.]

XXVI. The part played by insects in the epidemiology of plague. By D. T. Verjbitski, M.D., St Petersburg

XXVII. Report on experiments undertaken to discover whether the common domestic animals of India are affected by plague. By W. B. Bannerman and R. J. Kápadiâ

XXVIII. Additional experiments on the septicaemia in human plague, with an account of experiments on the infectivity of the excreta

XXIX. Observations on the bionomics of fleas with special reference to Pulex cheopis

XXX. The mechanism by means of which the flea clears itself of plague bacilli

XXXI. On the seasonal prevalence of plague in India . . . . .

XXXII. On the differential diagnosis of the plague bacillus from certain allied organisms

Arrhenius, S. On the Danysz Effect.

Aveline, H. T. S., Boycott, A. E. and Macdonald, W. F. Bacillus Dysenteriae of Flexner in Relation to Asylum Dysentery . . .

ARkwright, J. A. Observations on the Bacteriology of an Epidemic of Diphtheria in a School.

Armit, H. W. The Toxicology of Nickel Carbonyl. (Four Figures and Plates VII, VIII and IX.)

Blyth, M. W. The Examination of some Commercial Carbolic Acids and Disinfecting Powders

Boycott, A. E., Damant, G. C. C. and Haldane, J. S. The Prevention of Compressed-air Illness. (With 7 Figures and Plates IV, V and VI.) .

Boycotт, A. E. and Damant, G. C. C. Experiments on the Influence of Fatness on Susceptibility to Caisson Disease . . . . . .

Bulioch, W., Craw, J. A. and Atrin, E. E. On the Relative Efficacy of the Doulton, Berkefeld and Brownlow Filters. (Two Figures.) . . .

Chick, H. and Martis, C. J. The Principles involved in the Standardisation of Disinfectants and the Influence of Organic Matter upon Germicidal value 
Chick, H. and Martin, C. J. A Comparison of the Power of a Germicide Emulsified or Dissolved, with an Interpretation of the Superiority of the emulsified form

CHICK, H. An Investigation of the Laws of Disinfection. (Twenty-two Figures.)

Craw, J. A. On the Grain of Filters and the Growth of Bacteria through them. (Plates I and II.).

Currie, J. R. Abnormal Reactions to Horse Serum in the Serum Treatment of Cerebro-spinal Fever. (Three Figures.)

PAGE

698

Duckering, G. E. The Cause of Lead Poisoning in the Tinning of Metals. (One Figure.)

Green, A. B. Some Experiments on Immunity against Vaccinia in Animals

Green, A. B. The Influence of Temperature, and some other Physical Conditions, on Calf Vaccine. (One Figure.) . . . . . . . $\quad 52$

Grünbaum, A. S. Supersensitization to Alien Serum . . . . 9

MacConkey, A. T. Bile Salt Media and their advantages in some Bacteriological Examinations .

MacConkey, A. T. On the Relationship between Bacillus pestis and Bacillus pseudotuberculosis rodentium (Pfeiffer) . . . . . . . 335

MaIr, W. Experiments on the Survival of B. typhosus in Sterilised and Unsterilised Soil

MAIR, W. On the Rôle of Bacteria in the Biological Methods of Sewage Purification, with special reference to the Process of Denitrification

609

Reffer, M. A. and Willmore, J. G. The Driuking Water of Steamships .

Savage, W. G. and Gunson, C. H. An Outbreak of Poisoning from Infected Brawn

Südmersen, H. J. and Glenny, A. T. On some Non-specific Reactions of Mallein. (8 Charts.)

Symmers, W. St Clair and Wilson, W. J. Agglutination of Bacilli of the Alkaligenes, Colon and Typhoid Groups by the Blood Serum of Cases of Cerebro-spinal Fever

Thomson, J. D. Cultivation of the Trypanosome found in the Blood of the Gold-fish. (Plate III.) • • • • • • • • • • . .

WATSON, H. E. A Note on the Variation of the Rate of Disinfection with Change in the Concentration of the Disinfectant. (One Figure.) . .

WILson, W. J. Bacteriological Observations on Colon Bacilli infecting the Urinary Tract, with special remarks on certain Colon Bacilli of the "Anaerogenes" class 